\title{
PERCEIVED IMPACTS OF COMPANY WORKPLACE HEALTH PROMOTION ON EMPLOYMENT RELATIONSHIP
}

\author{
János Fehér \\ Károli Gáspár University of the Reformed Church in Hungary \\ Matthias Reich \\ University of Applied Sciences Ludwigsburg, Germany
}

\begin{abstract}
Workplace Health Promotion (WHP) as part of Workplace Health Management (WHM) is an emerging function within organizational HRM. Research has investigated the economic feasibility of WHM by examining health-related productivity losses and presenteeism but has also shown connections of WHM and employee reactions, i. a. happiness, confidence, job satisfaction, and perceptions of being cared for by employers. The goal of this paper is to examine possible impacts of WHM, and especially WHP on certain motivational and emotional aspects of the employment relationship, namely the perceived attractiveness of the employer, and perceived impacts of WHM/WHP on emotional atmosphere, work motivation, a commitment of the employees, and the number of voluntary quits.
\end{abstract}

Keywords: workplace health management and promotion, attractiveness of the employer, emotional atmosphere at the workplace, work motivation and commitment

DOI: http://dx.doi.org/10.15549/jeecar.v7i3.357

\section{WORKPLACE HEALTH PROMOTION AS AN EMERGING HRM FUNCTION}

Workplace Health Promotion (WHP) as part of Workplace Health Management (WHM) is an emerging function within today's organizational Human Resources Management system. The aim of WHM is to assist the organization and its members to be more productive by protecting and improving the health of employees. Productivity and health is an outcome of protecting health on the one hand and of offering opportunities for health promotion on the other (Kastner, 2010a, Slesina \& Bohley, 2011). Physical and psychological health are equally important for to be preserved and promoted. It is the individual who is responsible for $\mathrm{h} / \mathrm{h}$ status of health in the first place. Nevertheless, in order to maximize potentials in protecting and improving health, an active role of companies is necessary as well (Zimolong \& Elke G., 2010, Hymel et al, 2011, Ljungblad et al, 2014). Today a key issue in WHM becomes the the integration of traditional workplace health protection and the emerging WHP (workplace health promotion) practices. (Hymel et al.,2011).

Under scarcity in the labor supply, WHM and WHP can be especially important. Demographic tendencies have a negative impact on labour 
force supply. (Ehing \& Moog, 2013). As for another negative tendency, an increased level of absenteeism caused by psychological illnesses can be observed. (Techniker Krankenkasse, 2015). Changing workforce needs and expectations, challenges for employer branding and for offering special and customized employment experiences, and related impacts from underlying CSR philosophies and practices, can all be relevant causes for considering WHM as an important competitive advantage and a tool for fostering and communicating organizational and HRM values.

By today WHM is offered as an instrument for analyzing health-related productivity losses and presenteeism (working while sick). WHM uses absenteeism-data evaluations, health checkups and special offers for preserving and promoting health. (Wilke et al, 2015).

For monitoring and controlling the WHM activities, many of the used key-figures are difficult to calculate. Wellmann and Überle (2007) discuss the following frequently used ratios : (1) absence times, (2) costs of an undisturbed working hour, (3) labour turnover rate, (4) employee and customer satisfaction, (5) motivation, (6) performance, (7) productivity and (8) utilization of WHP activities. Out of the listed indicators only the (1), (3) and (7) are hard factor ratios. Data for calculating the remaining ratios can be gained merely from employee surveys. In this context Uhle and Treier (2015) claim that merely individual parameters and key figures like costs or absence times are insufficient to ensure a sustainable WHM.

As an example, Dickson-Swift et al. (DicksonSwift et al, 2014) offer results going beyond the traditional "key figure values" approach. They have found connections between WHM and employee reactions in Australia: "Employees report improvements in happiness, confidence, job satisfaction, physical health, work ethic, healthy behaviours ..., and a gain in enthusiasm for healthy choices ... When employers make an effort to do something for the good of the employees, such as offer flexible time, run a health information session or have a staff $B B Q$ at lunchtime, employees feel willing to repay this through extra hard work. Employees often reported a perception of being cared for by employers through the programs on offer..." In our present study our investigations will cover some of these motivational, emotional areas.

\section{ENVIRONMENTAL CHANGES AFFECTING EMPLOYMENT RELATIONSHIP}

The environment is becoming more dynamic and more complex, which is termed by Riekmann as "dynaxity" (1992).

Since the 80s, change tendencies have begun in areas such as internationalization and globalization, IT revolution, automation, robotization and biotechnological innovations, new quality expectations, and service economy, which have all impacted employees' value systems and lifestyles. Consequently, organizations underwent rapid transformations. Extra- and intra-organizational changes impacted work, employment and careers. Many organizations have experienced growing job complexity at all organizational levels. Nonroutine tasks demanded extra effort, initiative, and risk-taking on the side of employees. (see e. g. Dessler, 1994, 2000, Schermerhorn et al, 1994, Fehér, 2009a, Fehér, Kollár 2012).

This trend of dynaxity (environmental turbulence and complexity) has continued to the present. (Kastner 2013). It is becoming more difficult for individuals to keep stable orientation and certainty for decision-making. Everincreasing complexities would require ethical and inspiring leadership practices, whereas, paradoxically, toxic leadership can be a persistent reality within many contemporary organizations. (Hoffmann, Sergio, 2020)

Besides stress experienced at work, there are tendencies which make it difficult for the average employee to establish a stable living. This uncertainty and non-transparency increase the mental requirements for employees. In addition, by today, the acquired knowledge is more and more quickly getting out-of-date and to be renewed (Lohmann-Haislah 2012). For coping with challenges, LLL is required. (e.g. Eisermann et al, 2013). Under the $7 / 24$ work environment, the coincidence of uncertainty and the high expectations of investors or superiors lead to a high and often ill-making psychological pressure among employees. One result is the increase of absenteeism caused by psychological illnesses (Techniker Krankenkasse, 2015). 
WHM, including WHP may be instrumental in handling stress under new work environments. Smith et al. pointed out that "changing organizational health in a meaningful way has the potential to have positive and broad-based influence on personal health through the mechanism of experienced stress." (Smith et al, 2012) WHM can additionally improve l working atmosphere since the employees feel more esteemed by the proceeding of workplace health-related activities. .

\section{MATERIAL AND METHODS}

In our former research conducted in Germany and Hungary in the period 2014-2016, we have made investigations about the perceived impacts of sustainable and long-term oriented WHM, including WHP on the overall health of employees, on the attractiveness of the employer in the labor market, on the emotional climate of the organization, and the relations of WHM with leadership style and cooperation exchange within teams and between different teams. (Reich et al, 2015, Czeglédi et al, 2015, Fehér, Reich, 2016).

According to the results offered by Reich's $\mathrm{PhD}$ research (Reich, 2017) supervised by Fehér, employees think that WHM is an important factor in caring about their health. Reich concluded that certain leadership behaviors and team cooperation tendencies, the perceived attractiveness of the employer, and other perceptions about the employment relationship, are also statistically significant in relation to the investigated WHM practices. (Reich, 2017).

In this paper we focus on the topic of certain additional positive effects of WHM as perceived by employees. We use Reich's (2017) research design and methodology with an expanded data base. The conceptual framework of the research is illustrated by Figure 1. We report on possible impacts of WHM, and especially WHP on certain motivational and emotional aspects of the employment relationship, namely: the perceived attractiveness of the employer, perceived impacts of WHM/WHP on emotional atmosphere, work motivation, commitment of the employees, and the number of voluntary quits.

The data were gathered in Hungary and Germany by use of a standardized questionnaire in the time between 03/2014 and 01/2018. The underlying assumption behind a joint sample was that the two European countries are traditionally closely connected, both culturally and economically. (Reich, 2017) Within his European social model, Sapir (2006), for example, described both countries as continental. Under a classification of work organizations by Makó et al. (2009), both countries are in the same country cluster.

For the earlier parts of the research (Fehér, Reich, 2016, Reich, 2017) and for the actual extended data collection in Hungary and Germany, parttime students and course participants have been questioned. The questionnaire led to 298 evaluable answers, 172 in Hungary and 126 in Germany. The research is not representative of the sample and specifically does not allow comparisons between the two countries. As pointed out by Reich (2017), it can show a rough direction and identify tendencies within the surveyed organizations.

Of special interest in the purpose of this article are the survey questions, which dealt with the attractiveness of the employer, the emotional climate at the workplace, and if the motivation and commitment of the employees are increased by actions of a WHM and to what extent (Reich, 2017). The answer options for these questions (and the corresponding statistical values) were "Yes" (3), "No" (1) and "Don't know" (2) and for the expected extent "To a large extent" (3), "To a certain extent" (2) and "To a small extent" (1). 


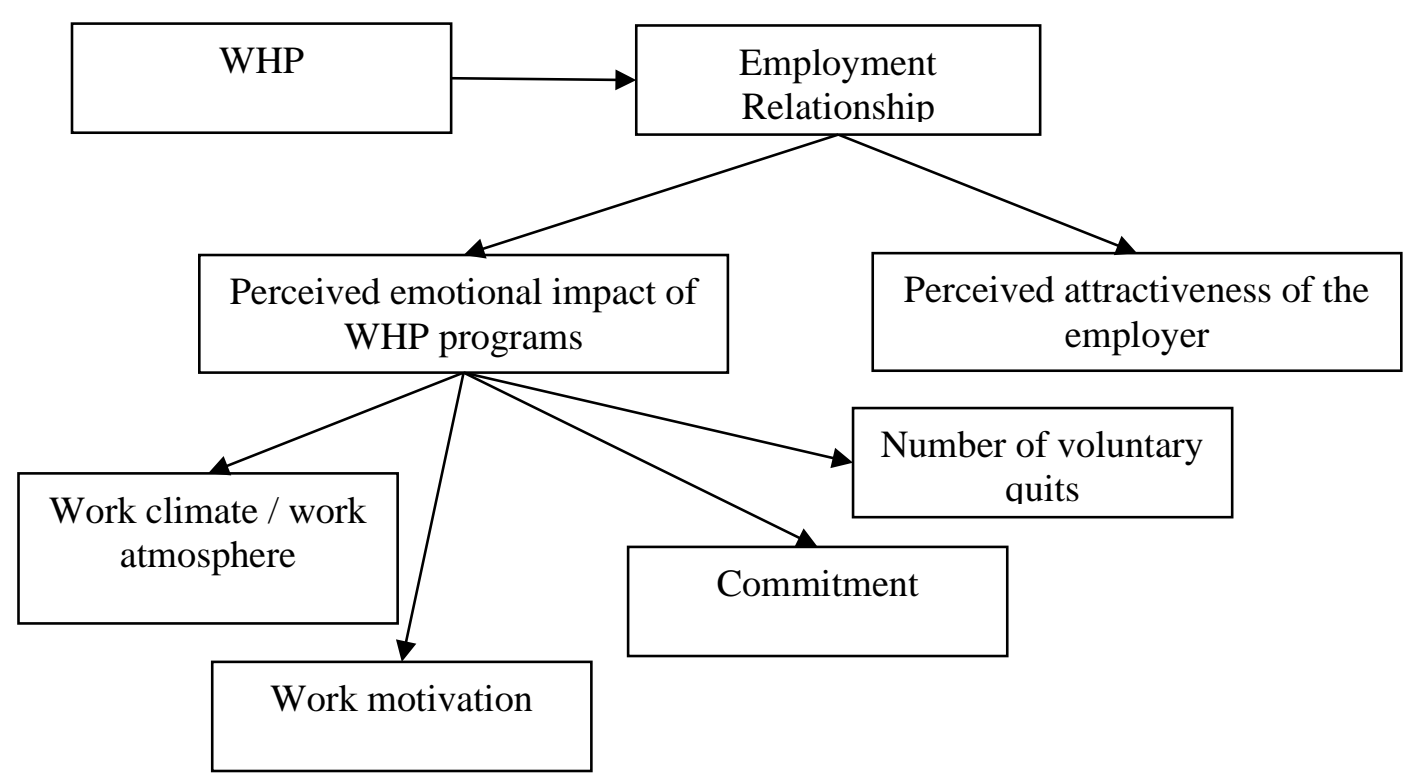

Figure 1: The effect of WHP on certain Employment Relationship dimensions

Source: Reich, 2017

In this paper, we present the hypotheses that were formulated and tested for Reich's (2017) earlier research, and we examine them, as aforementioned, with an expanded database.

\section{Hypothesis 1:}

“In employees' view, Workplace Health Management is statistically positively related to the attractiveness of the workplace/employer."

The question used in the questionnaire to evaluate this hypothesis was the following:

Do WHP programs make a workplace/employer more attractive for employees? (Reich, 2017)

Research has confirmed that WHM is a tool for enhancing the output and availability (in terms of productivity, health, and presenteeism) of existing employees (see, for example, Slesina \& Bohley, 2011, Wilke et al., 2015). In the era of demographic change and labour force scarcity (Ehing \& Moog, 2013), it is also of key relevance of how effective organizations become in attracting new workforce. Therefore, it is important to know whether WHM as a new HRM function is in a positive relationship with the employer's attractiveness within the labor market.

Hypothesis 2:

"WHM has perceived additional positive emotional impacts to the employment relationship.

a) To the emotional climate at the workplace.

b) To the work motivation of the employees.

c) To the commitment of the employees towards the organization.

d) To the number of voluntary quits."

Hypothesis $\mathrm{H} 2$ is based on Uhle and Treier (Uhle \& Treier, 2015) claiming that a one-sided orientation on conventional parameters is insufficient for WHM measures. Through $\mathrm{H} 2$ we search for possible organizational level, like a), b), c); and perceptional, like a), b), c), d) effects of WHM. By assuming a relationship between WHM and a), b) and c) we also follow DicksonSwift et al. (Dickson-Swift et al, 2014) who have found connections between WHM and positive employee emotional reactions.

Survey questions used to evaluate $\mathrm{H} 2$ included:

- "Do WHP programs contribute to the improvement of the emotional climate at the workplace?"

- "Do WHP programs increase the work motivation of the employees?" 
- "Do WHP programs increase the commitment of the employees toward the organization?"

- "Do WHP programs decrease the number of voluntary quits (turnover) of the employees?" (Reich, 2017)

For data processing, we used Microsoft Excel and software "R". To analyse the data amongst other methods, the one samples t-test was used. By using Likert scales and a sample size of 283 , the minimum requirements for using t-test are fulfilled.

\section{RESULTS}

$183(61 \%)$ of the respondents were male and $115(39 \%)$ were female.

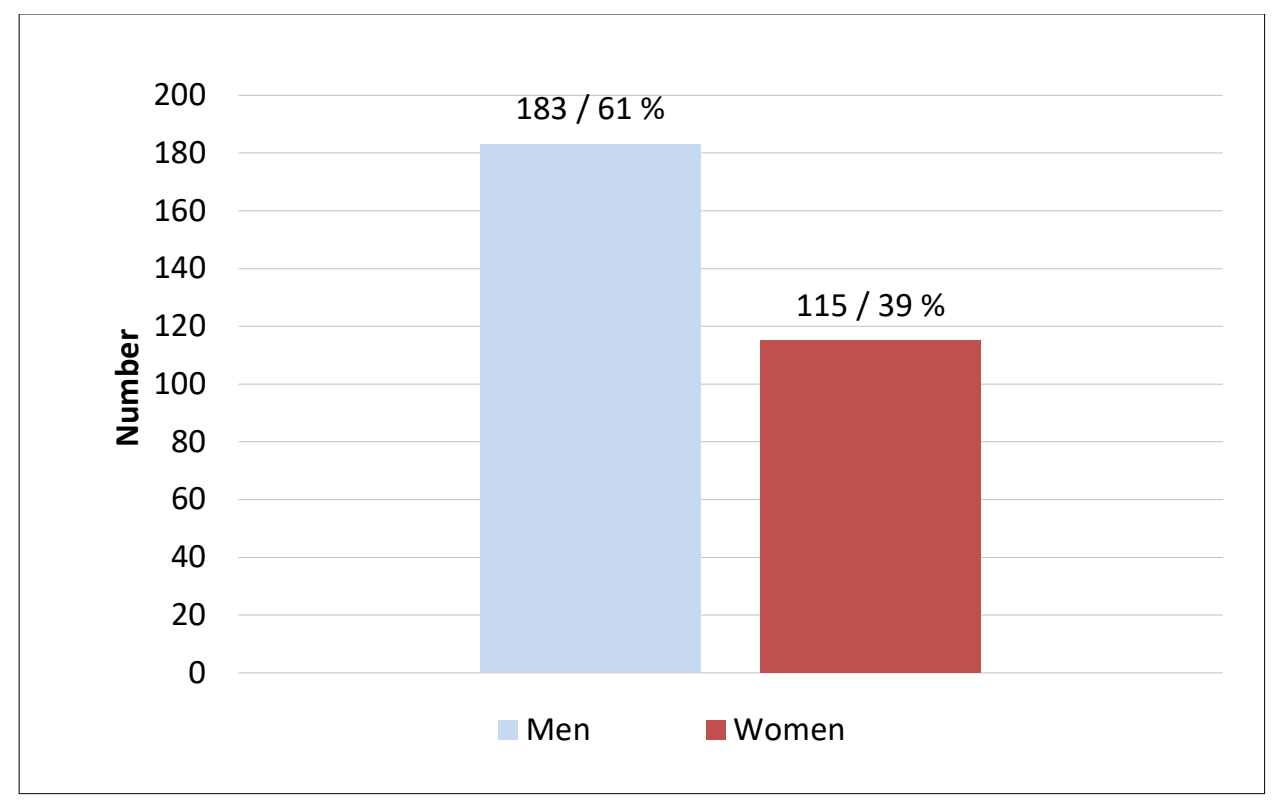

Figure 2: Respondents by gender

Source: author's work.

Only two (1\%) of the respondents were younger than 21 and five ( $2 \%$ ) older than 60 . The largest group was between 21 and 30 years old
(116 / $39 \%$ ), followed by the group between 3140 with $37 \%$. 


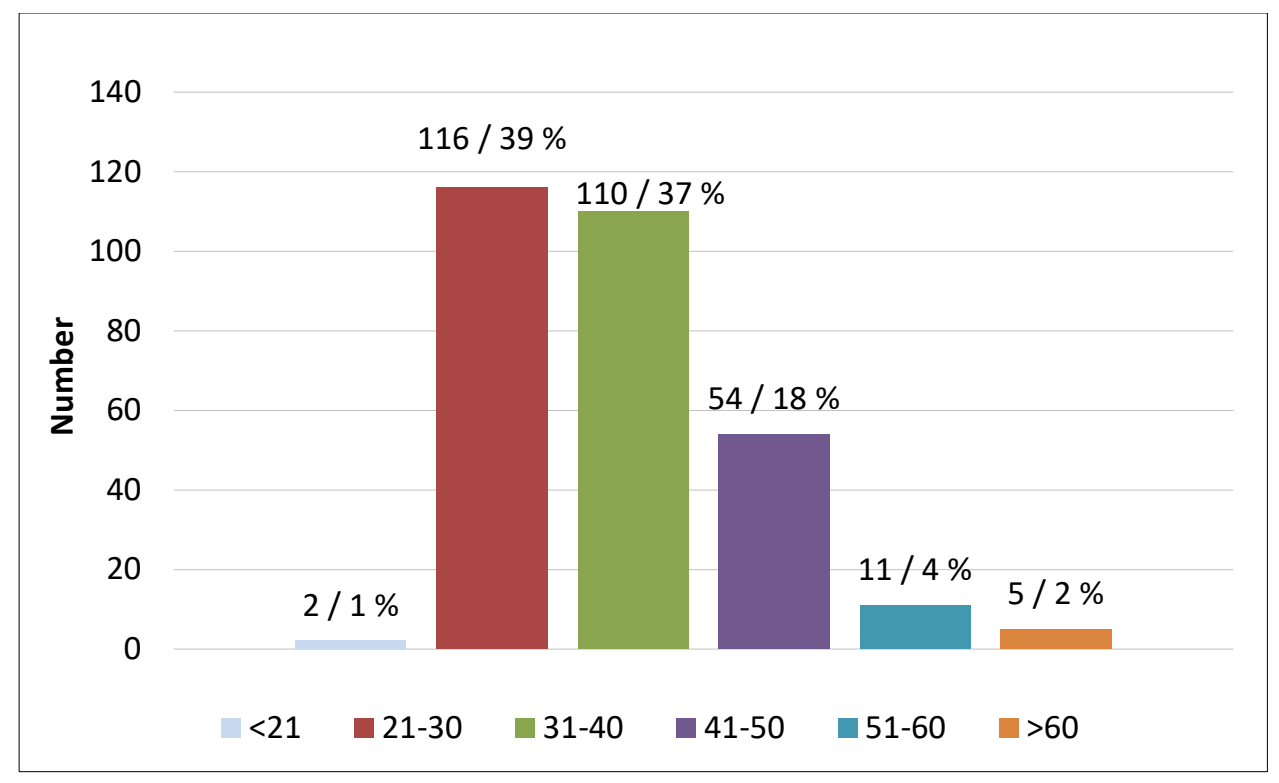

Figure 3: Respondents by age

Source: author's work.

As shown in Figure 4 the largest group was working in companies with private ownership
(41\%), followed by multinational ownership (38 $\%$ ) and state ownership with $17 \%$.

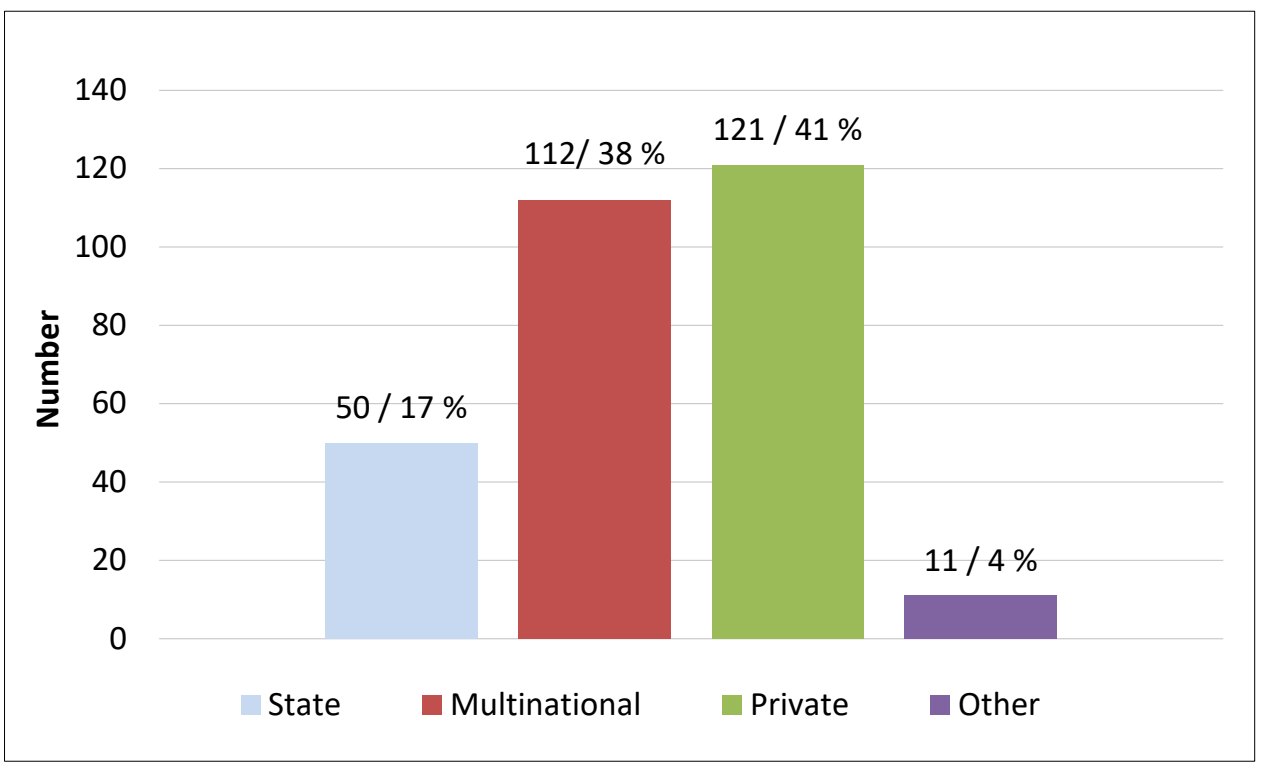

Figure 4: Respondents by ownership structure

Source: author's work.

Most respondents (46.2\%) work for mediumsized companies with 20-499 employees. $43.4 \%$ work for big companies (500 or more employees) and $10.4 \%$ work for small organizations. 




Figure 5: Respondents by number of people working for the organization Source: author's work.

As referred to Reich (2017), Hypothesis 1 tests whether in employees view WHM is statistically positively related to the attractiveness of the workplace/employer.



Figure 6: (Hypothesis 1) Histogram for employment attractiveness

Source: author's work.

For $82 \%$ of the respondents, Workplace Health Management increases the employer's attractiveness for employees who are already working for the company (see Table 1 ).

Table 1: (Hypothesis 1) Distribution for employment attractiveness 


\begin{tabular}{|c|c|c|c|}
\hline \multicolumn{4}{|c|}{ More attractive? (Total) } \\
\hline & Item & Total & Percent \\
\hline Yes & 3 & 239 & $82 \%$ \\
\hline No & 1 & 38 & $13 \%$ \\
\hline \multirow[t]{2}{*}{ Don`t know } & 2 & 15 & $5 \%$ \\
\hline & & 292 & $100 \%$ \\
\hline \multicolumn{4}{|c|}{ If "Yes": To what extent? } \\
\hline Large & 3 & 79 & $33 \%$ \\
\hline Some & 2 & 153 & $65 \%$ \\
\hline \multirow[t]{2}{*}{ Small } & 1 & 5 & $2 \%$ \\
\hline & & 237 & $100 \%$ \\
\hline
\end{tabular}

Source: author's work.

One third of those responding "Yes" in "C1" stated that the WHM contributes to a large

extent to the attractiveness of the employer, , while $65 \%$ attribute to some extent.

Table 2: (Hypothesis 1) Distribution for employment attractiveness - organizations without and with WHM

\begin{tabular}{|c|c|c|c|c|c|}
\hline \multicolumn{2}{|c|}{$\begin{array}{c}\text { More attractive? } \\
\text { (without and with WHM) }\end{array}$} & \multicolumn{2}{|c|}{ without WHM } & \multicolumn{2}{|c|}{ with WHM } \\
\hline & Item & Total & Percent & Total & Percent \\
\hline Yes & 2 & 153 & $78 \%$ & 86 & $90 \%$ \\
\hline No & 1 & 30 & $15 \%$ & 8 & $8 \%$ \\
\hline \multirow[t]{2}{*}{ Don't know } & 0 & 13 & $7 \%$ & 2 & $2 \%$ \\
\hline & & 196 & $100 \%$ & 96 & $100 \%$ \\
\hline \multicolumn{6}{|c|}{ If “'Yes”: To what extent? } \\
\hline Large & 3 & 39 & $26 \%$ & 40 & $26 \%$ \\
\hline Some & 2 & 107 & $71 \%$ & 46 & $30 \%$ \\
\hline \multirow[t]{2}{*}{ Small } & 1 & 5 & $3 \%$ & 0 & $0 \%$ \\
\hline & & 151 & $100 \%$ & 86 & $57 \%$ \\
\hline
\end{tabular}

Source: author's work.

In line with the results of Reich (2017) dividing the responses into two groups, one without WHM and one with WHM, 78\% in the group without WHM think that WHM increases the attractiveness of the employer for them and 90\% in the group with WHM think that way (this is a difference of $12 \%$ ).

For this item, a one-sample t-test is used, too. The null hypothesis is that there is no positive 
correlation between WHM and the employer's attractiveness, which is a mean equal to or less than 2. Because the t-value is higher than the critical value, the null hypothesis can be rejected. This means that with $95 \%$ certainty, there is a positive correlation.

Table 3: (Hypothesis 1) One sample t-Test for the item C1 (attractive for employees)

\begin{tabular}{|l|l|l|l|l|l|}
\hline \multicolumn{6}{|c|}{ One Sample t-test } \\
\hline & mean of $x$ & 95\% CI Lower & 95\% CI Upper & $t$ & df \\
\hline C1 & 2,688356 & 2,621703 & & 17,041 & 291 \\
\hline & HA: greater & & & & \\
\hline & H0: mean $<=2$ & & & \\
\hline
\end{tabular}

Source: author's work.

Viewing the results of the statistics and the ttest, it can be concluded that Hypothesis 1 is confirmed.

With reference to Reich (2017), in Hypothesis 2 we examine whether "WHM has perceived additional positive emotional impacts on the employment relationship in relation to:

a) the emotional climate at the workplace

b) the work motivation of the employees.

c) the commitment of the employees towards the organization. d) the number of voluntary quits"

Table 4 and Table 5 show the results for the four items. Overall, we were able to get 294 evaluable answers for item a) (emotional climate), 295 for item b) (work motivation), 294 for item c) (commitment of the employees towards the organization) and 291 for item d) (number of voluntary quits).

Table 4: (Hypothesis 2) Distribution for a) emotional climate and b) work motivation

\begin{tabular}{|l|l|l|l|l|l|}
\hline \multicolumn{2}{|l|}{} & \multicolumn{2}{|c|}{ a) emotional climate } & \multicolumn{2}{c|}{ b) work motivation } \\
\hline & Item & Total & Percent & Total & Percent \\
\hline Yes & 3 & 226 & $77 \%$ & 214 & $73 \%$ \\
\hline No & 1 & 36 & $12 \%$ & 46 & $16 \%$ \\
\hline
\end{tabular}

\begin{tabular}{|l|l|l|l|l|l|} 
Don't know & 2 & 32 & $11 \%$ & 35 & $12 \%$ \\
\hline Total number & & 294 & $100 \%$ & 295 & $100 \%$ \\
\hline Mean & & 2,65 & & 2,57 & \\
\hline $\begin{array}{l}\text { Standard } \\
\text { deviation }\end{array}$ & & 0,689 & & 0,748 & \\
\hline
\end{tabular}


Continues Table 4.

\begin{tabular}{|l|l|l|l|l|l|}
\hline \multicolumn{2}{|l|}{ If "Yes": To what extent? } & & & & \\
\hline Large & 3 & 90 & $40 \%$ & 80 & $37 \%$ \\
\hline Some & 2 & 129 & $57 \%$ & 114 & $53 \%$ \\
\hline Small & 1 & 7 & $3 \%$ & 20 & $9 \%$ \\
\hline Total "Yes" & & 226 & $100 \%$ & 214 & $100 \%$ \\
\hline
\end{tabular}

Source: Author's work.

The mean of the total results of a) is 2.65 (see Table 4). This seems to indicate a clear positive relationship between WHM and the emotional climate. In fact, $77 \%$ of the 294 respondents answered with "Yes". (see Table 4). From them, $40 \%$ think that WHM increases the emotional climate significantly (see Table 4). The means for item b) counts 2.57 (see Table 4). $37 \%$ of the 214 (see Table 4) positive respondents answered WHM increases work motivation to a large extent.

The distributions for a) and b) are shown by Table 4 and Figure 7 and Figure 8.

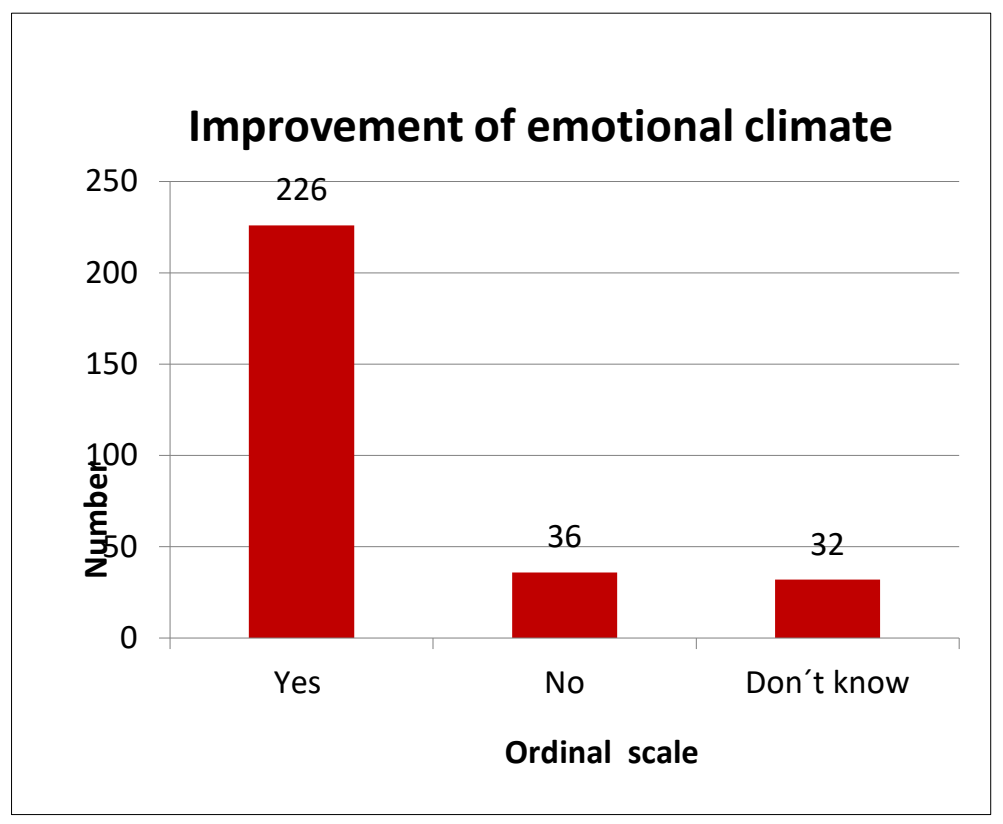

Figure 7: (Hypothesis 2) Histogram for a) (improvement of emotional climate) Source: author's work. 


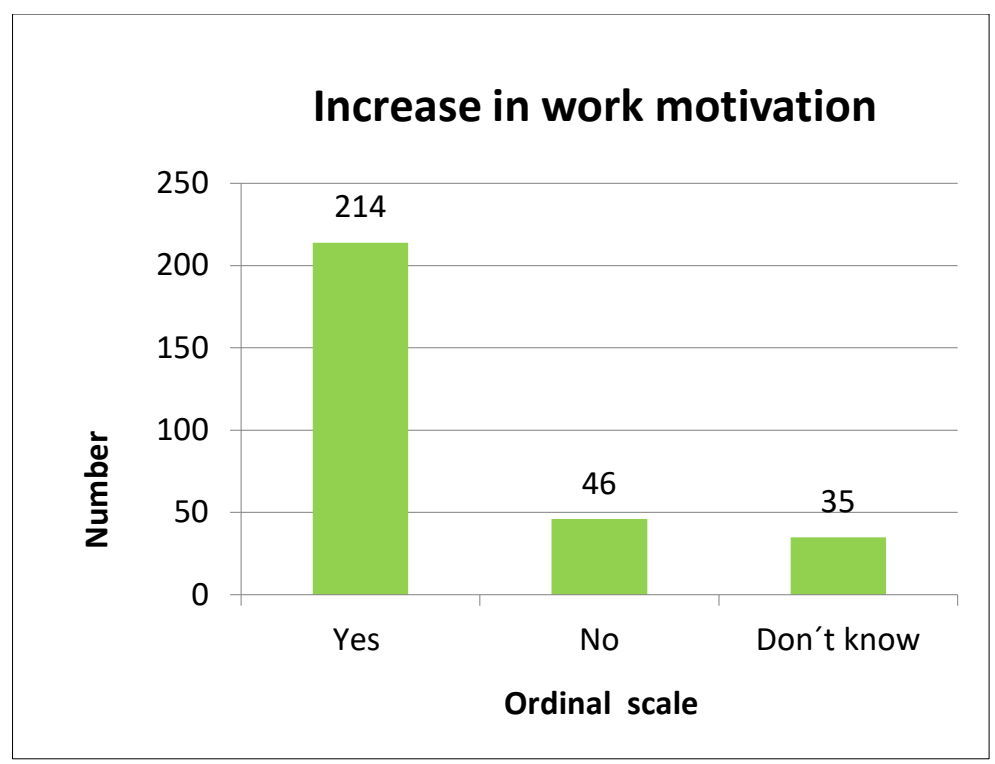

Figure 8: (Hypothesis 2) Histogram for b) (an increase of work motivation) Source: author's work.

For item c) we had 294 respondents. The mean is 2.47 (see Table 5). 195 (66\%) of the 294 (see Table 5) respondents thought that WHM would increase the commitment of the employees toward the organization (34\% of them attributed to a large extent).

Table 5: (Hypothesis 2) Distribution for c) (increase commitment) and d) (decrease turnovers)

\begin{tabular}{|c|c|c|c|c|c|}
\hline & & c) & ommitm & d) & urnovers \\
\hline & Item & Total & Percent & Total & Percent \\
\hline Yes & 3 & 195 & $66 \%$ & 110 & $38 \%$ \\
\hline No & 1 & 58 & $20 \%$ & 88 & $30 \%$ \\
\hline Don't know & 2 & 41 & $14 \%$ & 93 & $32 \%$ \\
\hline Total number & & 294 & $100 \%$ & 291 & $100 \%$ \\
\hline Mean & & 2,47 & & 2,08 & \\
\hline $\begin{array}{l}\text { Standard } \\
\text { deviation }\end{array}$ & & 0,803 & & 0,823 & \\
\hline \multicolumn{6}{|c|}{ If "Yes": To which extent? } \\
\hline Large & 3 & 66 & $34 \%$ & 31 & $29 \%$ \\
\hline Certain & 2 & 96 & $49 \%$ & 56 & $52 \%$ \\
\hline Small & 1 & 32 & $16 \%$ & 21 & $19 \%$ \\
\hline Total "Yes" & & 194 & $100 \%$ & 108 & $100 \%$ \\
\hline
\end{tabular}

Source: author's work. 
In contrast to results for items a), b) and c), the mean for d) is only 2.08 . Only $38 \%$ (see Table 5 ) of the respondents think that WHP programs decrease the number of voluntary quits of the employees. $30 \%$ stated with a clear "No."
Distributions for c) and d) are below shown by Table 5 and Figures 9 and 10.

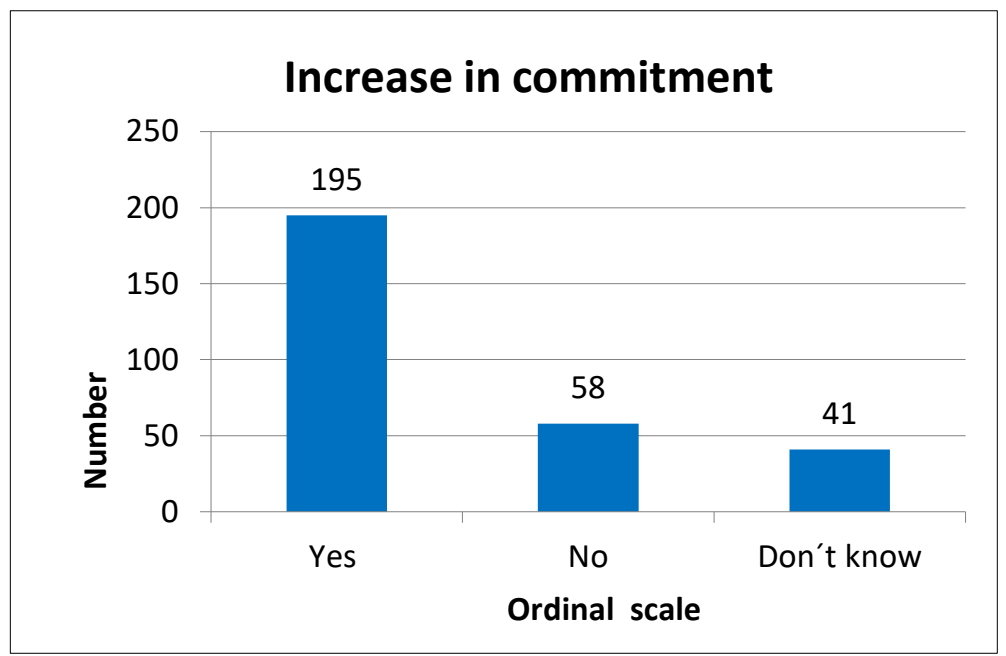

Figure 9: (Hypothesis 2) Histogram for c) (increase commitment)

Source: author's work.

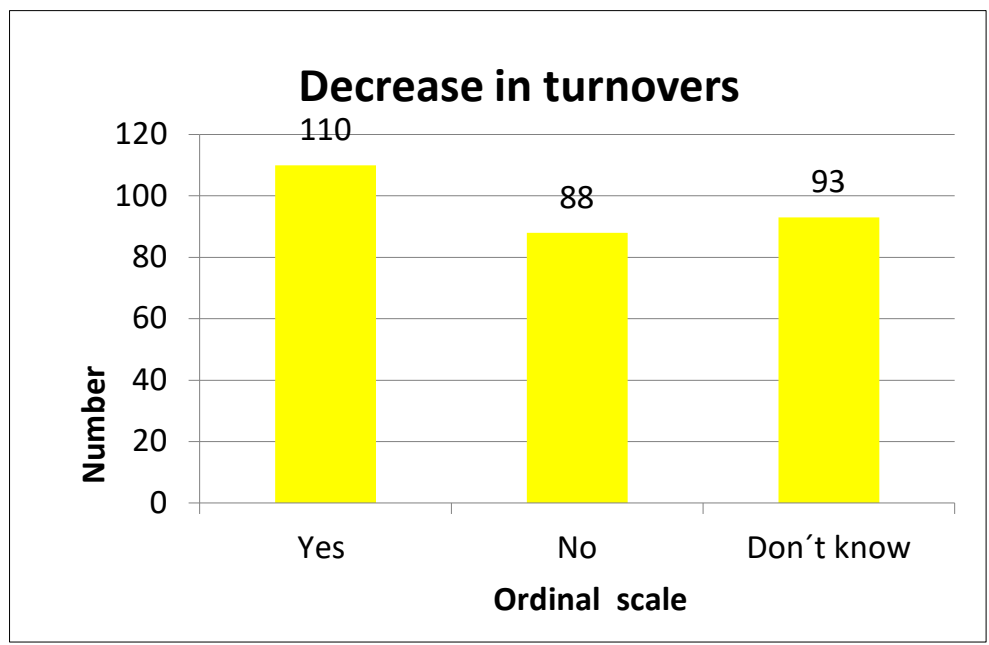

Figure 10: (Hypothesis 2) Histogram for d) (decrease turnovers)

Source: author's work.

To strengthen the conclusions drawn in the first step about a positive correlation of WHM and the four items only for items a), b) and c), the second step is to perform a one-sample t-test. The null hypothesis for the four items is that there is no positive correlation between WHM and each of the four items. To validate this statement, the null hypothesis is defined as a mean equal to or less than 2 . 
Table 6: (Hypothesis 2) One sample t-Test for the item a), b), c) and d)

\begin{tabular}{|c|c|c|c|c|c|}
\hline \multicolumn{6}{|c|}{ One Sample t-test } \\
\hline & mean of $x$ & 95\% CI Lower & 95\% CI Upper & $\mathrm{t}$ & $\mathrm{df}$ \\
\hline a) & 2,6463 & 2,5799 & & 16,076 & 293 \\
\hline b) & 2,5695 & 2,4977 & & 13,086 & 294 \\
\hline c) & 2,4660 & 2,3887 & & 9,9441 & 293 \\
\hline d) & 2,0756 & 1,9960 & & 1,5674 & 290 \\
\hline & \multicolumn{2}{|c|}{ HA: greater } & & & \\
\hline & \multicolumn{2}{|c|}{ HO: mean $<=2$} & & & \\
\hline
\end{tabular}

Source: author's work.

The results for the items (in consistency with the earlier research by Reich, 2017) are the following:

a) (emotional climate): Because the t-value is higher than the critical value, the null hypothesis can be rejected. This means that with $95 \%$ certainty, there is a positive correlation.

b) (work motivation): Because the t-value is higher than the critical value, the null hypothesis can be rejected. This means that with 95\% certainty, there is a positive correlation.

c) (increase commitment): Because the $t$ value is higher than the critical value, the null hypothesis can be rejected. This means that with 95\% certainty, there is a positive correlation.

d) (decrease turnovers): Because the t-value is lower than the critical value, the null hypothesis can't be rejected. This means that with $95 \%$ certainty, there is no positive correlation.

The results of the t-test are the same as the results of the first step: a), b), c) seem to be in a positive correlation with WHM, while d) is not positively correlated with WHM.

Combining the results of the statistics and the t-test described in this article, Hypothesis 2 is only confirmed partly for a), b) and c). Part d) is not confirmed.

\section{SUMMARY/DISCUSSION}

H1 hypothesis 1 is verified, supporting Reich's (2017) results, that WHM is statistically positive related to the attractiveness of the workplace or employer. This means as well that WHM may be able to improve company image. This can be seen partly in contrast to the results of a study of the FOM (2013). According to the FOM study, 52,4\% of the respondents told WHM was not an important factor for them to work for their company. As interpreted earlier by Reich (2017) in his research on a smaller sample, the contrast can be explained by the difference in the meaning of the terms of "an image improvement of a company" and "a factor bearing importance in working for a company". Besides the time factor referred to, WHM is a relatively new component within the system of employment gratifications.

Previous research has confirmed that WHM is a tool for enhancing the output and availability (in terms of productivity, health, and presenteeism) of existing employees (see, for example, Slesina \& Bohley, 2011, Wilke et al., 2015). In the era of demographic change and labour force scarcity, the organizational ability to attract a new workforce becomes crucial. Our research supports that WHM as a new HRM function - beyond its positive impact on present employees - has a positive relationship with the employer's attractiveness within the labor market.

$\mathrm{H} 2$ hypothesis 2 is partially verified. Positive correlations were found between WHM and good/better emotional climate at the workplace, 
work motivation and commitment of the employees towards the organization. Nevertheless, in the respondents' eyes WHM would not lead to a decreased number of voluntary quits.

Based on previous literature (see, for example, Uhle \& Treier, 2015 and Dickson-Swift et al, 2014), under $\mathrm{H} 2$ we have made investigations on some organizational levels, including emotional and motivational indicators related to WHM. Our research has supported previous literature: we have confirmed the positive effects of WHM on three investigated factors of the investigated employment relationship (emotional climate, work motivation, and commitment towards the organization). Data do not support the relationship between WHM and the fourth factor (voluntary quits). In this way, the fourth factor can be viewed as an indicator of the limits of the positive effects of WHM. The reason for the fact that employees don't think WHM leads to a decreased number of voluntary quits may be that the effects of the WHM are very positive, but limited regarding certain aspects of the employment relationship. (Reich, 2017)

This article deals with the expectations the employees have on WHM and its additional effects. Conclusions can be drawn, as already suggested by Reich (2017), about the reasons of the relation of WHM with the attractiveness of the workplace and the perceived positive emotional impacts. First, WHM would increase the attractiveness of an employer because of the general interest of employees in their own health. It can also be concluded that the employees feel confident that the actions of WHM lead to a better emotional climate at the workplace. (Reich, 2017) Following Suliman and Al Harethi (2013), who found a positive correlation between work climate and job performance, it can be suggested that WHM leads to better job performance. A reason for this assumption may be that through WHM the employees feel more respected by the employer. (Reich, 2017) Also employees' communication and collaborative atmosphere can be enhanced through participating in actions of a WHM.

Further conclusion can be drawn regarding why employees think WHM increases work motivation and increases commitment towards the organization. Reich (2017) suggested that "caused by the perceived own importance for the company, the motivation to work for this company may improve, too. The same reason may be responsible for the expected improved commitment of the employees." In this regard, the additional effects of motivation and commitment that are generally related to company benefits programs (see for example: Poór et al., 2018) can be very important as well. Based on Faragher et al.'s results on the correlation between job satisfaction and mental health (Faragher, 2005), in the light of the relations of WHM to emotional and motivational factors, it can be suggested that WHM not only directly but also indirectly impacts on the health of organizational members. .

Regarding employees' willingness to leave the company, we refer to Allen et al. (2010) who have found a negative correlation between willingness to leave and satisfaction and organizational commitment. Elci and Alpkan (2009) found that job satisfaction is negatively related to the intention to leave. Our research investigated the direct relationship between Workplace Health Management and the expectations of the number of voluntary quits. . We can confirm, as suggested earlier by Reich (2017) that in this case, the positive effects of WHM have their clear limits, and for the intentions of the employees to designate from the company, other factors may be more important.

\section{REFERENCES}

Allen, D., Bryant, P., \& Vardaman, J. (2010): Retaining Talent: Replacing Misconceptions with Evidence-Based Strategies, Academy of Management Perspectives, 2010, Vol. 24, No. 2, pp. 48-64.

Czeglédi, Cs., Reich, M., \& Fonger, J. (2015): Workplace Health Management as a Diversity Management Tool, American International Journal of Social Science, Vol. 4 (5), P. 192-198, 2015, ISSN 2325-4149 (Print), ISSN 2325-4165 (Online).

Dessler, Gary (2000): Human Resource Management. Prentice Hall International, Inc., Upper Saddle River, New Jersey

Dickson-Swift, V., Fox, C., Marshall, K., Welch, N., \& Willis, J. (2014): What Really Improves 
Employee Health and Wellbeing, International Journal of Workplace Health Management, Vol. 7, No. 3, Pp. 138-155, Doi: 10.1108/Ijwhm-10-2012-0026.

Ehing, D. \& Moog, S. (2013): Erwerbspersonenund Arbeitsvolumenprojektionen bis ins Jahr 2060, Journal for Labour Market Research, Vol. 46, No. 2, pp. 167-182.

Eisermann, M., Erdel, B., \& Janik, F. (2013): Lebenslanges Lernen und Trends in der Weiterbildung, Wirtschaftsdienst 2013, Volume 93, Issue 7, pp. 496-498, ISSN: 0043-6275.

Elci, M. \& Alpkan, L. (2009): The Impact of Perceived Organizational Ethical Climate on Work Satisfaction, Journal of Business Ethics, Volume 84, pp. 297-311, Doi: 10.1007/S10551-008-9709-0.

Faragher, E.B., Cass, M., \& Cooper, C.L. (2005): The Relationship Between Job Satisfaction and Health: A Meta-Analysis, Occupational and Environmental Medicine, 2005, Vol. 62, Issue 02, pp. 105-112.

Fehér János, Kollár Péter (2012): Transformational Leadership: Concepts and Cultural Transfer Problems. In: Illés B. Csaba (Szerk.): Proceedings of The International Conference on Management of Human Resources, 2012, Volume II, Gödöllő, Szent István University. ISBN: 978-963-269-295-1. Rosental Kft., pp. 445-452

Fehér, J. (2009): The Evolution of The Concept of and Selected Aspects of Employee Development in Transformational Leadership. Bulletin Of Szent István University, Gödöllő, 2009, ISSN 1586-4502, pp. 276-288

Fehér, J. \& Reich, M. (2016): Leadership Behavior in Companies with and without a Workplace Health Management, Polish Journal of Management Studies, Vol. 13 (1), pp.50 - 58, ISSN 2081-7452,

Doi: 10.17512/Pjms.2016.13.1.05.

FOM (2013): Betriebliches Gesundheitsmanagement In Deutschland 2013 - Stand Der Dinge, FOM Hochschule für Oekonomie \& Management, KCS Kompetenz Centrum für Statistik und Empirie. Retrieved On 30.05.2017 From Https://Www.Fom.De/Fileadmin/Fomalt/Kc/
Kcs/130513_Betriebliches_Gesundheitsman agement_Ergebnisdiagramme.Pdf.

Hymel, P., Loeppke, R., Baase, C. et al. (2011): Workplace Health Protection and Promotion, Journal of Occupational and Environmental Medicine, Vol. 53, Issue 6, pp. 95-702, ISSN 1076-2752.

Hoffmann, E. P., Sergio, R. P. (2020): Understanding the effects of toxic leadership on expatriates' readiness for innovation: an Uzbekistan case, Journal of Eastern European and Central Asian Research, Vol.7 No.1 pp. 26-38

Kastner, M. (2010): Leistungs- und Gesundheitsmanagement - Psychische Belastung und Altern, Inhaltliche und Ökonomische Evaluation; Papst Science Publishers 2010; ISBN: 3899676572.

Kastner, M. (2013): Ganzheitliches Gesundheitsmanagement In Unternehmen, In: Stock-Homburg (Ed.), Handbuch Strategisches Personalmanagement (2nd Ed.), pp. 521-552, Wiesbaden, Doi 10.1007/978-3-658-00431-6.

Ljungblad C., Granström, F., Dellve, L., \& Akerlind, I. (2014): Workplace Health Promotion and Working Conditions as Determinants of Employee Health, International Journal of Workplace Health Management, Vol. 7, Issue 2, pp. 89-104.

Lohmann-Haislah, A. (2012): Stressreport Deutschland 2012 - Psychische Anforderungen, Ressourcen und Befinden, Bundesanstalt für Arbeitsschutz und Arbeitsmedizin, Dortmund 2012.

Makó, Cs., Illéssy, M., Csizmadia, P., Kirov, V., \& Galev, T. (2009): Changes in Work in Transformation Economies. The Case of The New Member States, Katholieke Universiteit Leuven, Higher Institute of Labour Studies, 2009, ISBN 978-90-8836-016-9

Poór, J., Kovács, I. É., Mázásné Dinnyés, H., Mack, Á., Fehér, J. (2018): Flexible benefits Cafeteria plan. How the characteristics of the firms affect the system of cafeteria plans, Journal of Eastern European and Central Asian Research, Vol.5 No.1 pp. 1-20

Reich, M. (2017): Workplace Health Management as an Emerging Function 
Within Corporate Human Resource Management - Results of a Survey in Germany and Hungary. PhD Dissertation, Szent István University, Gödöllő

Reich, M., Czeglédi, Cs., \& Fonger, J. (2015): Expectations of Employees on the Effects of the Workplace Health Management as a Part of an Internal Diversity Management - An Explorative Study, Business Trends, Vol. 5 (2), P. 49-58, 2015, ISSN 1805-0603.

Rieckmann, H. (1992): Dynaxibility - Oder Wie „Systemisches“ Management in der Praxis funktionieren Kann, In: Klaus Henning, Bertram Harendt (Eds.), Methodik und Praxis der Komplexitätsbewältigung, Duncker \& Humblot, Berlin 1992.

Sapir, A. (2006): Globalization and The Reform of European Social Models, Jourmal of Common Market Studies, 2006, Volume 44, No. 2, pp. 369-390

Schermerhorn, J.R. Jr., Hunt, J.G., \& Osborn, R.N. (1994): Managing Organizational Behavior. John Wiley \& Sons, Inc., New York

Slesina W., Bohley S. (2011): Gesundheitsförderung und Prävention in Settings: Betriebliches Gesundheitsmanagement, In Schott, T., Hornberg, C., Die Gesellschaft Und Ihre Gesundheit, pp. 619-633, ISBN 978-3-53117581-2.

Smith, S., Makrides, L., Schryer Lebel, F., Allt, J., Montgomerie, D., Farquharson, J., Macdonald, M.J., \& Szpilfogel, C. (2015): The Healthy Lifeworks Project: The Role of Organisational Health in the Personal Health of Employees, International Journal of Workplace Health Management, 2012, Vol. 5, Number 3, pp. 194-209.

Suliman, A. \& Al Harethi, B. (2013): Perceived Work Climate and Employee Performance in Public Security Organizations in The UAE, Transforming Government: People, Process and Policy, Vol. 7, Number 3, Pp. 410-424, Doi: $10.1108 / \mathrm{Tg}-03-2012-0001$.

Techniker Krankenkasse 2015: Gesundheitsreport 2015 - Gesundheit Von Studierenden, Techniker Krankenkasse (Ed.), Hamburg 2015, ISSN 1610-8450.
Uhle, T. \& Treier, M. (2015): Betriebliches Gesundheitsmanagement Gesundheitsförderung In Der Arbeitswelt Mitarbeiter Einbinden, Prozesse Gestalten, Erfolge Messen, Springer Verlag, 3rd Edition, Berlin, ISBN 978-3-662-46723-7.

Wellmann, H. \& Überle, M. (2007): Ökonomische Aspekte der BGF. in: IQPRForschungsbericht Nr. 3/2007 Teilhabe am Arbeitsleben durch Betriebliches Gesundheitsmanagement, Institut Für Qualitätssicherung in Prävention und Rehabilitation Gmbh an der Deutschen Sporthochschule Köln, S. 54, ISBN 978-39811175-4-7.

Wilke, C., Elis, T., \& Biallas, B. (2015): Gesundheitsbedingte Leistungseinbußen bei der Arbeit durch Präsentismus, Prävention und Gesundheitsförderung, 2015, Vol. 10 Issue 1, pp. 35-40, Doi: 10.1007/S11553014-0468-8.

Zimolong, B. (2001): ArbeitsschutzManagement-Systeme, In Zimolong, B. (Ed.), Management Des Arbeits- Und Gesundheitsschutzes - Die Erfolgreichen Strategien Der Unternehmen, Pp. 13-30.

Zimolong B. \& Elke G. (2010): Management of Work Site Health Promotion: A Review. In: Work Site Health Promotion, Bochumer Berichte Zur Angewandten Psychologie Nr. 26/10, Ruhr Universität Bochum, pp. 4-10. 


\section{ABOUT THE AUTHORS}

János Fehér, email: feherdr@t-online.hu

Dr. János Fehér is an Associate Professor and Academic Director of HRM Program at Károli Gáspár University of the Reformed Church in Hungary. He teaches Management and HRMrelated subjects. He earned his Ph.D. from Szent István University, where he holds an Affiliated Professor position. He served as Associate Professor and Program Director at IMC/International Management Center (the first Graduate School of Business in the CEE region, in affiliation with the University of Pittsburgh); and Visiting Associate Professor at Temple University Philadelphia, CWRU Cleveland, and Budapest Corvinus University. He has been a Consultant/ MD Program Director/Trainer for leading Hungarian and international companies.

Dr. Matthias Reich is a Professor at the University of Applied Sciences Ludwigsburg, Germany, School of Public Administration and Finances. He graduated in 1999 as Diplom - Finanzwirt (FH) / Bachelor of Laws (LL.B.). From then on until 2019, he worked as a tax officer at the financial administration of the Federal State Baden-Württemberg. 2001-2004 he studied Business Management postgraduate at the University of Lahr (Wissenschaftlichen Hochschule Lahr) and finished with „Dipl. - Kaufmann / Master of Arts (M.A.)”. He earned his Ph.D. degree in Business and Administration Sciences from Szent István University in Hungary in 2017. He is a lecturer at the Chamber of Industry and Commerce, and in 2012-2015 he was a teacher at the University for Applied Science of Heilbronn, too 